\title{
Elite Corruption in Indonesia's Bureaucracy, Case Study of Kudus District Regent
}

\author{
Budi Puspo Priyadi \\ \{budipuspo@gmail.com\} \\ Universitas Diponegoro, Indonesia
}

\begin{abstract}
Corruption among the bureaucratic elite is still occurs in Indonesia. Many public officials, especially the government elite, are ensnared in corruption cases. This paper tries to answer that problem why the elit corruption such as MT, Kudus District Regent who returns to dealing with corruption cases. Based on these problems, research needs to be done to analysis how it happens. This study uses secondary data from newspapers and interpretive analysis. This result shows that MT has been caught up in a situation of political pragmatism so contrary to the moral ethics of a leader and he is not able to preserve his religious name. Some officials also involved in corruption cases of office buying and selling in which it goes against the spirit of bureaucratic reform and MT as the main actor of that. Political parties also do not set a good example when presenting candidates who have been involved in corruption cases. By this case we need to reformulate how the government in preventing and suppressing corruption will be able to realize a clean and authoritative government. In observing the deeper and wider scope, it needs to be done further research with a qualitative case study.
\end{abstract}

Keywords: Elite Corruption, Political Pragmatic

\section{Introduction}

Corruption among the bureaucratic elite is a disease that still occurs in Indonesia despite various preventions by creating regulations and forming commissions to solve the corruption problem. The Old data showing based on the results of Kompas daily Research and Development poll in March 2005 in ten major Cities of Indonesia shows that 62 percent of respondents said the government apparatus has not been freed from corruption, collusion, and nepotism every time it runs its work is a real reflection of bureaucratic failure. Only 15 percent of respondents who rated the government apparatus have been exempt from this dirty practice (Kompas, March 26, 2005). It is also in line with the incident of an official from Central Java province, MT who corruption of the education and infrastructure funds of Kudus District in 2004. The corruption case carried out by the Indonesian bureaucratic apparatus occurred in a change where it shows there is still an abuse authority of the state apparatus for their personal benefit [1]. The Data from Databoks.katadata.co.id accessed in October 22, 2019 showed that accumulative figures from 2004 to 2019 there were 199 officials in echelons II, III, and I were committed corruption.

Cases of corruption and abuse of authority or often-called "abuse of power" needs to be reviewed in depth as to why it still happens even though reform movements, especially in the bureaucratic sphere, continue. The part or position of the workplace in government agencies is often a contested arena in order these situations must be able to care for the boss honestly in 
order to occupy a profitable place. According to Sutherland [2] in terms of promotion, not using objective criteria, such as education or generality so that various forms of licking attitudes and nepotism [3]. The research from Yahya and Mutiarin [4] on rank and position in Yogyakarta bureaucracy found that people in contesting positions and careers in the office use various efforts, such as going to shamans or paranormal to get support, wearing a short pants (ngolor), obsequiously to superiors in order to get special attention, and establishing personal relationships.

This condition also happened to MT, while serving as Kudus District Regent there was an auction case of second echelon office in four agencies in fiscal year 2019, which was then processed by the Corruption Eradication Commission (KPK). It means clearly do not conform to the principles in modern bureaucracy that rely on meritocracy. The pattern of relationships that occur between employees who work in the "wet" place and the boss or person in charge of determining the place of duty tends to be patronage [5]. The relationship creates a unity of interest between the patron and the client to maintain a situation that benefits both parties, based on the need for subordinate protection on the one hand and the status of superiors on the other, which is endorsed morally and psychologically by the principle of respect [6]. Indonesian bureaucracy despite its Western form and model, but its practice follows traditional power relations such as patron-client relations [7][8][9]. Former president Suharto was known to be adept at managing patronage with his subordinates, the military group [10] and was able to take full control of the bureaucracy ranks with patrimonialism supported by military force [11].

\section{Methodology}

This research uses library study methods, such as analysis of competent newspaper news documents, literature studies. This research is a type of descriptive research, namely by using a secondary data and then making interpretive analysis. Kudus City was chosen as a research area with the consideration of the figure that became research has a record of accomplishment as regional head in 2003 to 2008 . Then in 2018 nominated again and elected as regional head in the same place, but in 2019 re-entangled corruption cases. In addition to looking at the character, Kudus District area is famous for its religious community attitude. This is reflected in the concept of "Gus-jigang", an attitude or character that saints must have, namely good morality, good in reading Quran, and good at trading [12][13]. One of the important features of Kudus City is a Tower as a symbol of the traces of Sunan Kudus (Muslim Emperor) as a spreader of Islam so that Kudus society are called "ngisor tower" (under the tower) which reflects the obedience of reading Quran [14].

\section{Results and Discussion}

The problem of corruption can be approached from three aspects that affect ethical behavior within the organization, namely individual characteristics, organizational factors, and opportunities [15]. This article emphasizes the individual characteristics, especially awareness in terms of moral issues. The corruption of the bureaucratic elite that still occurs today reflects that bureaucratic reform efforts have not fully run its maximum. The most common and easy definition of corruption is the abuse of public power for its own gain [16]. Smith at the 
beginning of the New Order has reviewed corruption in Indonesia, defining corruption as the use of public resources for personal purposes [17].

The opinion mentioned by Haller and Shore [18] that corruption was a perverted behavior from the official duties of state officials for personal or business gain. According to the head of Corruption Eradication Commission (KPK) in 2010 named Busyro Muqodas, Indonesia's corruption rate in 2014 ranks fourth among Asian countries. There are 150 regional officials and 8 governors who are being investigated by the KPK due to corruption cases (Republika, Friday, May 6, 2011). Additionally, in 2014 there has been a very sharp increase in cases of officials entangled in corruption, as presented by Djohermansyah Djohan, Director General of Regional Autonomy of the Ministry of Internal Affairs, there are 318 people out of a total of 524 regional heads and representatives who are caught up in corruption. (Republika.co.id February 14, 2014). Statistically this data shows more than 60 percent of local officials are involved in corruption, meaning this phenomenon of corruption is already a very serious problem in Indonesia. According to Mauro [19], Zaire, Indonesia, and Haiti were mired in poverty due to widespread corruption [20][21].

Although Kudus District has experienced corruption as happened in 2004, namely the education assistance and infrastructure fund where it was carried out by MT, but the Human Development Index of Kudus District is still better than the figure of Central Java Province as seen in the table 1 .

Table 1. Human Development Index of Kudus District and Central Java Province

\begin{tabular}{|l|c|c|c|}
\hline \multicolumn{1}{|c|}{ Year } & $\mathbf{2 0 1 0}$ & $\mathbf{2 0 1 4}$ & $\mathbf{2 0 1 8}$ \\
\hline Kudus district & 69,22 & 72 & 74,58 \\
\hline Central Java Province & 66,09 & 68,78 & 71,12 \\
\hline
\end{tabular}

Source: www.ipm.bps.go.id.

The achievement of Human Development Index in Kudus District better than Central Java Province may be because it reaches from the districts in Central Java is still low. This means that the pace of development is not the same between districts, depending on the potential. Kudus District ranks fourth out of 32 districts in Central Java. The region has a variety of industries, companies and small and medium-enterprise economic centers that are able to drive productive economic activities. There are 13,482 companies with 10,954 small and medium-enterprises with various types of businesses and the most is the cigarette industry so it all has a positive impact on macroeconomics. According to Bahruddin [22] mentioned that it is not separated from the spirit of "Gus-jigang" that exists in the community of Kudus District, especially Muslim entrepreneurs.

Corruption is one of the shortcuts or slashes that a person does to gain wealth in a way that does not follow the norms and rules of law. This was actually reviewed by Indonesian anthropologists in the 1970 under the term mentality [23][24][25]. When the New Order, corruption occurred so massively that the term "corruption of worshippers" emerged then Suharto's most great sin was that he had cultivated a corrupt mentality that then spread into part of the nation's culture [26]. Suharto instead managed to develop crony capitalism, where his close family was heavily involved in business activities [27][28]. Because of this, Suharto's family is also committed corruption, especially in the 1980 and 1990 [29].

Suharto's centralistic system of government changed since his rule ceased with the reform movement in 1998. The reforms then transformed the centralized system of government into regional autonomy. However, the opportunity for decentralization of governance seems to be leveling the practice of Collusion, Corruption and Nepotism of 
formerly centralized officials, since decentralization shifted to the region [30]. The area became an arena of power struggle, both executive and legislative and it was heavily loaded with political money [31]. Regional Autonomy is the embodiment of a decentralized policy that is considered one of the strategies for bureaucratic reform [32]. However, in reality, decentralization in Indonesia failed in reforming the state apparatus because the old system was still running [33].

Corruption is one form of shortcut to earn money. The factor that makes a person do shortcuts or slashes was because of the loss of shameless [34]. In Javanese, society there is a term "wirang" which means shame, and then there is the word "wirangan", which is to be ashamed of being caught doing something that should not be like corruption. If the Javanese say "wis ora nduwé wirang", which means to have no shame then the person has been said "dudu wong Jowo", not Javanese because they have no self-esteem. In other areas, as in bugis-Makassar communities are known the concept of "siri" which means the same as "wirang".

Interesting thing in the case of bureaucratic elite corruption as done by MT, he was born in Ujung Pandang or now called Makassar. According to the data, he had been living in Pinrang in elementary school. Pinrang is regency located in the north of Makassar city, 185 $\mathrm{Km}$ from the city. At primary school age, 6 to 12 years, MT may not yet know the concept of "siri" which is the philosophy of bugis life. Further education was pursued in Java, starting from Junior High School in Pacitan, Senior High School in Tulungagung, and then took Bachelor Degree to Master Program in Semarang. Since graduating from Bachelor Degree, he has worked in the government environment of Kudus District and in 1991 served as head of the Public Works Office, a "wet" Local Government Task Force. People looked up there is a wet and dry workplace where it had to do with how much material profit will be gained [25].

People who occupy the position of "wet" but do not get rich are called fools and morons [35]. MT was ensnared in corruption of educational aid funds in the 2004-2005 financial years, but withdrew it in 2014 while he was Kudus District Regent. In February 2015, he was found guilty and sentenced to one year and 10 months in prison plus a fine of 100 million rupiah subside of 3 months.

In July 2019, MT was arrested by Corruption Eradication Commission (KPK) with the case of buying and selling the positions of several heads of service in Kudus District environment. At that time, he served as the Second Regent of Kudus. This event shows how money politics still happens. Wet areas are certain strategic positions where a person will have the opportunity to earn additional income and the base salary. An example of a strategic position is the Head of a Regional Task Force (SKPD), especially one that handles many physical development projects. In Javanese vocabulary there is a term "loh" which means a country that is so fertile that whatever is planted must grow well [36] so that it then connotes with the word teles, which means wet. From that phenomenon the word teles (wet) is then associated with a fertile place and contrary to the word crisp (dry), i.e. an infertile place [37]

During the reign of the New Order, bureaucratic agencies such as Doane or Pabean, namely offices to take care of in and out of goods at the port as well as immigration were wet areas so it became a hotbed of corruption [38]. In the case of the sale and positions conducted by MT the mode is the same, around the sale and strategic SKPD-SKPD positions so that Corruption Eradication Commission also arrested several second echelon officials involved with the case. One of the strategic SKPD, namely DPPKAD an agency that is the spearhead in the implementation of local government, both basic duties and auxiliary duties must be offset by the local native income (PAD). Given his strategic position, the position of head of the office is very expensive and his officials, namely the secretary of DPPKAD were also caught 
by Corruption Eradication Commission. In addition to DPPKAD the position of head of office that is used as a buying and selling event among others Disdukcapil, Tourism Agency, and PUPR which also includes a "wet" office. Therefore, in many cases it is uncommon for people who attempt to seize the office to have no hesitation in providing considerable funds in return to the authorities deciding [1][34].

When it comes to preventing corruption, the New Order government has made preventive efforts; photos of corruptors are shown on National Television Channel (TVRI) in order to shame them in this way. Now with several private television stations, while covering cases of corrupt arrests, suspects still smile and do not feel ashamed. Corruption Eradication Commission to create a special uniform for corruption suspects so that his sense of selfrespect is continued when covered by the mass media. However, the culture of shame did not work because the corruptor is already thick face [9].

MT who became the main character in this writing when caught by Corruption Eradication Commission and wearing an orange vest his facial expression does not show a sad facial expression, even still smiling. Strangely, MT figure that used to be entangled in corruption cases and run for regional head anyway is still elected; as if the public has forgotten that, he once had a bad record. Some people in Kudus City also still give a positive response when MT is captured the second time, they do pray for it to always be steadfast. It can happen because MT image when serving as regent succeeds in advancing Kudus Regency and does not waste budget for unnecessary things.

MT's case shows the failure of political parties to conduct political education when carrying out candidates who have committed corruption and showing permissiveness, but that is according to Titi Anggraini, Executive Director of Perludem because there is no legal norm prohibiting it (Kompas, 22 August 2020). The Constitutional Court passed the ruling number 56/PUU-XVII/2019 stating that former corruption convicts are required to wait five years after getting out of prison only to be allowed to run as regional heads. Seeing these conditions, political parties should have a moral sensitivity not to bring in candidates who have committed corruption. When a political party does not do it then the culture of shame is also not an important thing to note so this becomes a moral crisis collectively. The party, whose base is religious as well as the cultural religious background of Kudus Society, reflected in the concept of "Gus-jigang" became had no effect on the election case of MT twice as well as the corruption he committed.

The issue of corruption in Indonesia has been held for a long time [29] and when it is now increasingly widespread among the bureaucratic elite then efforts to reform are one thing to do. The Indonesian government also seems intent on serious bureaucratic reform, although it is often criticized half-heartedly for still focusing on the interests of power (Kompas, March 26, 2005).

\section{Conclusion}

The elite corruption case that befell MT can be summed up at some point. MT, which has served for two periods, was unable to absorb the spirit of "Gus-jigang" where it became a hallmark of Kudus Society as a moral reference. He was also unable to maintain a good name and still relied on moneymaking motives when he became a bureaucratic apparatus and regional chief. The name also has religious connotations, even the ruling party is Islamic, and namely PPP, PKB and Hanura, but it has no effect in his behavior as regional head. It seems that individual characteristic factors, organizational factors, and opportunities are integrated so 
that twice MT can commit acts of corruption. In the case of buy and sell, position shows that the patron-client culture still exists so that bureaucratic reforms have not shown encouraging results because there are still regional heads selling positions and there are officials willing to buy positions. MT's corruption case also shows that the political system, particularly about the record of accomplishment of prospective regional heads needs to be really considered and that is reinforced by clear regulation.

\section{References}

[1] S. Kristiansen and M. Ramli, "Buying an Income: The Market for Civil Service Positions in Indonesia," Contemp. Southeast Asia, 2006.

[2] H. Sutherland, Terbentuknya Sebuah Elite Birokrasi. Jakarta: Sinar Harapan, 1983.

[3] S. Suherry, "Politik Pemberantasan Korupsi di Indonesia," Otoritas J. Ilmu Pemerintah., 2017.

[4] M. Rafi Yahya and D. Mutiarin, "Model Lelang Jabatan Di Pemerintah Daerah Daerah Istimewa Yogyakarta," J. Gov. Public Policy, 2015.

[5] World Bank, The Little Data Book 2003. 2003.

[6] F. Magnis-Suseno, Javanische Weisheit und Ethik. 2015.

[7] J. Cotton, "Asian power and politics: the cultural dimensions of authority," Int. Aff., 1986.

[8] S. Kartodirdjo, Kebudayaan pembangunan dalam perspektif sejarah. Yogyakarta: Gadjah Mada University Press, 1987.

[9] S. P. W, Bandit Berdasi Korupsi Berjamaah: Merangkai Hasil Kejahatan Pasca-Reformasi. Yogyakarta: Kanisius, 2008.

[10] H. Crouch, "Patrimonialism and Military Rule in Indonesia," World Polit., 1979.

[11] R. Theobald, "Patrimonialism," World Polit., 1982.

[12] N. Said, "Spiritual Enterprenership Warisan Sunan Kudus: Modal Budaya Pengembangan Ekonomi Syari’Ah Dalam Masyarakat Pesisir,” Equilib. J. Ekon. Syariah, 2014.

[13] A. K. Nawali, "Nilai-nilai Pendidikan Islam dalam Filosofi Hidup 'Gusjigang' Sunan Kudus dan Implikasinya Terhadap Kehidupan Masyarakat Di Desa Kauman Kecamatan Kota Kudus" J. Pendidik. Agama Islam, 2018.

[14] Sumintarsih; Siti Munawaroh; Christriyati Ariani, Gusjigang: Etos Kerja Dan Perilaku Ekonomi Pedagang Kudus. Yogyakarta: Kementerian Pendidikan dan Kebudayaan Balai Pelestarian Nilai Budaya Bali, 2016.

[15] D. Heaton, T. Carlisle, and I. Brown, "A Human Resource Development Program to Foster Individual Moral Development in Indian Corporations: Aligning Corporate Governance with Natural Law," in Corruption and Governance in Asia, 2003.

[16] V. Tanzi, "Corruption Around the World: Causes, Consequences, Scope, and Cures," IMF Staff Pap., 1998.

[17] T. M. Smith, "Corruption, Tradition and Change," Indonesia, 1971.

[18] D. Haller and C. Shore, "Corruption: anthropological perspectives," Anthropol. Cult. Soc., 2005.

[19] P. Mauro, "Corruption and growth," Q. J. Econ., 1995.

[20] I. Ehrlich and T. L. Francis, "Bureaucratic corruption and endogenous economic growth," in Journal of Political Economy, 1999.

[21] G. R. Montinola and R. W. Jackman, "Sources of corruption: A cross-country study," Br. J. Polit. Sci., 2002.

[22] A. Bahruddin, "Spirit Gusjigang Kudus dan Tantangan Globalisasi Ekonomi, " J. Penelit., 2015.

[23] Koentjaraningrat, "Kebudayaan Mentalitet dan Pembangunan," in Bab 1, bab 2, bab 3, bab 4, 1974.

[24] Suhartono W. Pranoto, Serpihan budaya feodal. Yogyakarta: Yogyakarta: Agastya Media, 2001.

[25] S. Sairin, "The Impact of Globalization on Indonesian Socio-Cultural Life," Int. Area Stud. 
Rev., 2004.

[26] L. Santoso, D. Meyriswati, and I. N. Alfian, "Korupsi dan mentalitas: kendala kultural dalam pemberantasan korupsi di Indonesia," Masyarakat, Kebudayaan dan Politik, 2014.

[27] H. B. Cheah, "Monopoly rights and wrongs: Two forms of intellectual property rights violations in Asia," in Fighting Corruption in Asia: Causes, Effects and Remedies, 2003.

[28] N. Girling, "Total quality management and the UK's national standards of management competence," Total Qual. Manag., 1997.

[29] J. S. Quah, "Singapore in 1987: Political Reforms, Control, and Economic Recovery," Southeast Asian Aff. 1988, 1988.

[30] P. Bardhan, "Corruption and Development: A Review of Issues,” J. Econ. Lit., 1997.

[31] B. Platzdasch, "Localising Power in Post-authoritarian Indonesia: A Southeast Asia Perspective," J. Contemp. Asia, 2011.

[32] D. Hirschmann, "Development management versus third world bureaucracies: A brief history of conflicting interests," Dev. Change, 1999.

[33] R. Robison, "Looking back on the asian crisis: The question of convergence," Asian J. Soc. Sci., 2003.

[34] S. Sairin, Mobilitas Sosial dan Beban Kultural: Tinjauan Antropologis Fenomena KKN di Indonesia. Yogyakarta: Universitas Gadjah Mada, 1999.

[35] L. Santoso, D. Meyriswati, I. N. Alfian, J. S. Indonesia, U. Airlangga, and J. A. Surabaya, "Korupsi dan mentalitas: kendala kultural dalam pemberantasan korupsi di Indonesia Corruption and mentality: cultural obstacles in combating corruption in Indonesia," Masyarakat, Kebud. Dan Polit., 2011.

[36] G. Mujanto, Konsep Kekuasaan Jawa Penerapanannya oleh Raja-raja Mataram. Yogyakarta: Kanisius, 1987.

[37] M. G. Logsdon, "Indonesia's Civil Service in the New Order: Consolidation, Growth, and Change,” J. Soc. Issues Southeast Asia, 1992.

[38] D. S. Zagoria and H. McDonald, "Suharto's Indonesia," Foreign Aff., 1982. 